\title{
Metal-free synthesis of 1,5-disubstituted 1,2,3-triazoles
}

Andrey Bubyrev, Ksenia Malkova, GrigoryKantin, Dmitry Dar'in*and Mikhail Krasavin*

Saint Petersburg State University, Saint Petersburg, 199034 Russian Federation

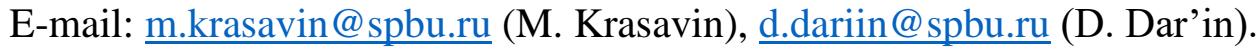

http://www.krasavin-group.org/

\section{Table of Contents}

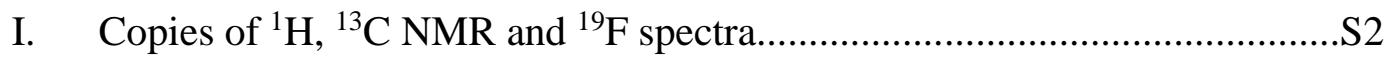


Copies of ${ }^{1} \mathrm{H}\left(400.13 \mathrm{MHz}, \mathrm{CDCl}_{3}\right)$ and ${ }^{13} \mathrm{C}\left\{{ }^{1} \mathrm{H}\right\}\left(100.61 \mathrm{MHz}, \mathrm{CDCl}_{3}\right)$ spectra of $\mathbf{2 b}$
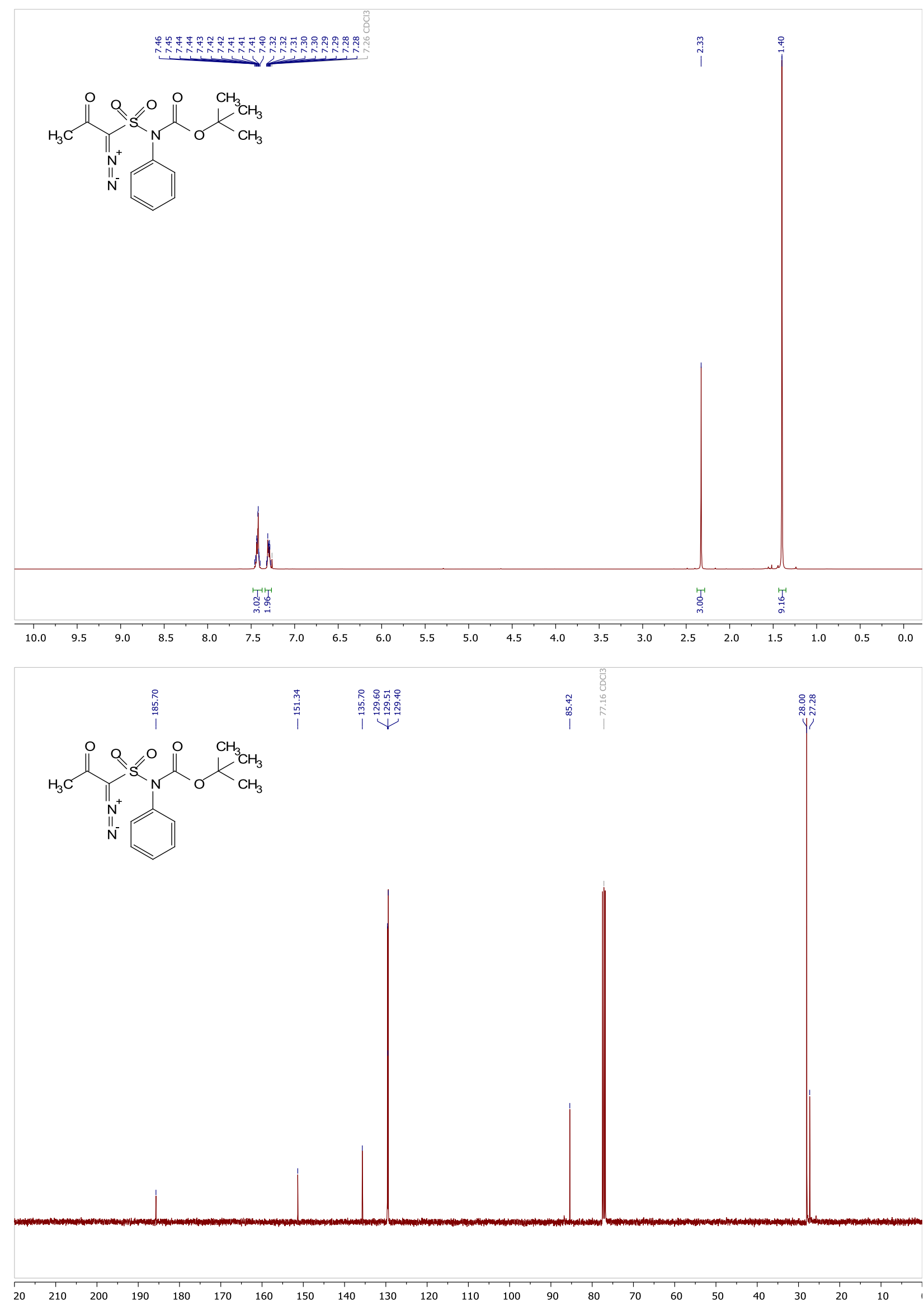
Copies of ${ }^{1} \mathrm{H}\left(400.13 \mathrm{MHz}, \mathrm{CDCl}_{3}\right)$ and ${ }^{13} \mathrm{C}\left\{{ }^{1} \mathrm{H}\right\}\left(100.61 \mathrm{MHz}, \mathrm{CDCl}_{3}\right)$ spectra of $\mathbf{1 e}$

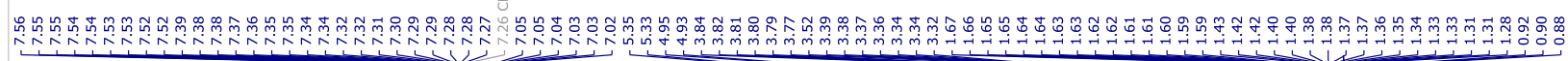<smiles>CCCCN1N=N[C@H](S(=O)(=O)N(C)c2ccccc2)[C@H]1c1ccc(C(C)(C)C)cc1</smiles>
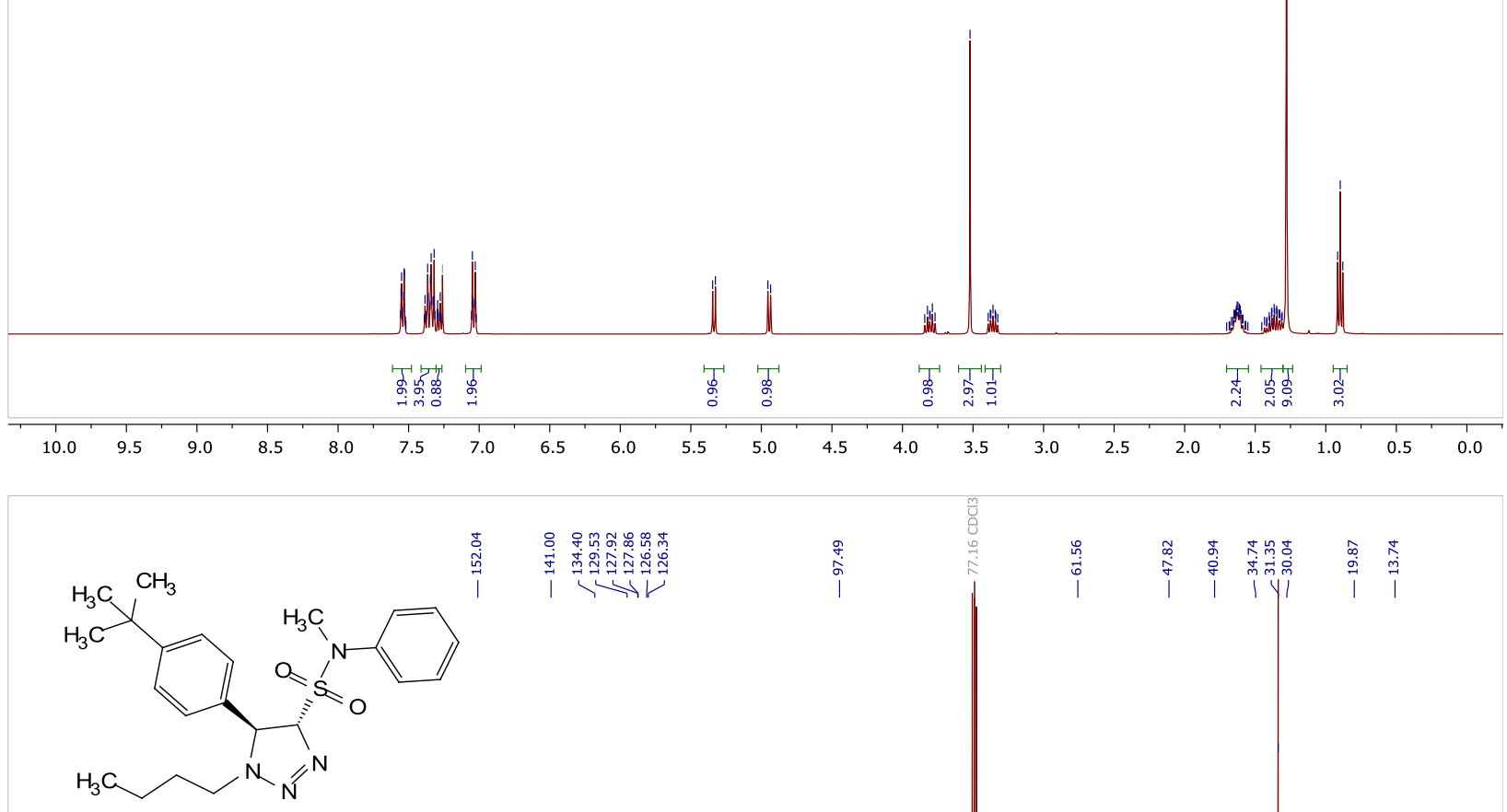
Copies of ${ }^{1} \mathrm{H}\left(400.13 \mathrm{MHz}, \mathrm{CDCl}_{3}\right)$ and ${ }^{13} \mathrm{C}\left\{{ }^{1} \mathrm{H}\right\}\left(100.61 \mathrm{MHz}, \mathrm{CDCl}_{3}\right)$ spectra of $\mathbf{1 j}$

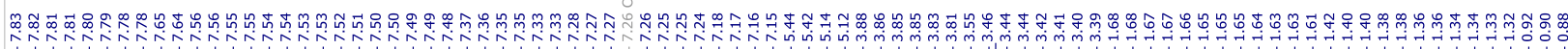
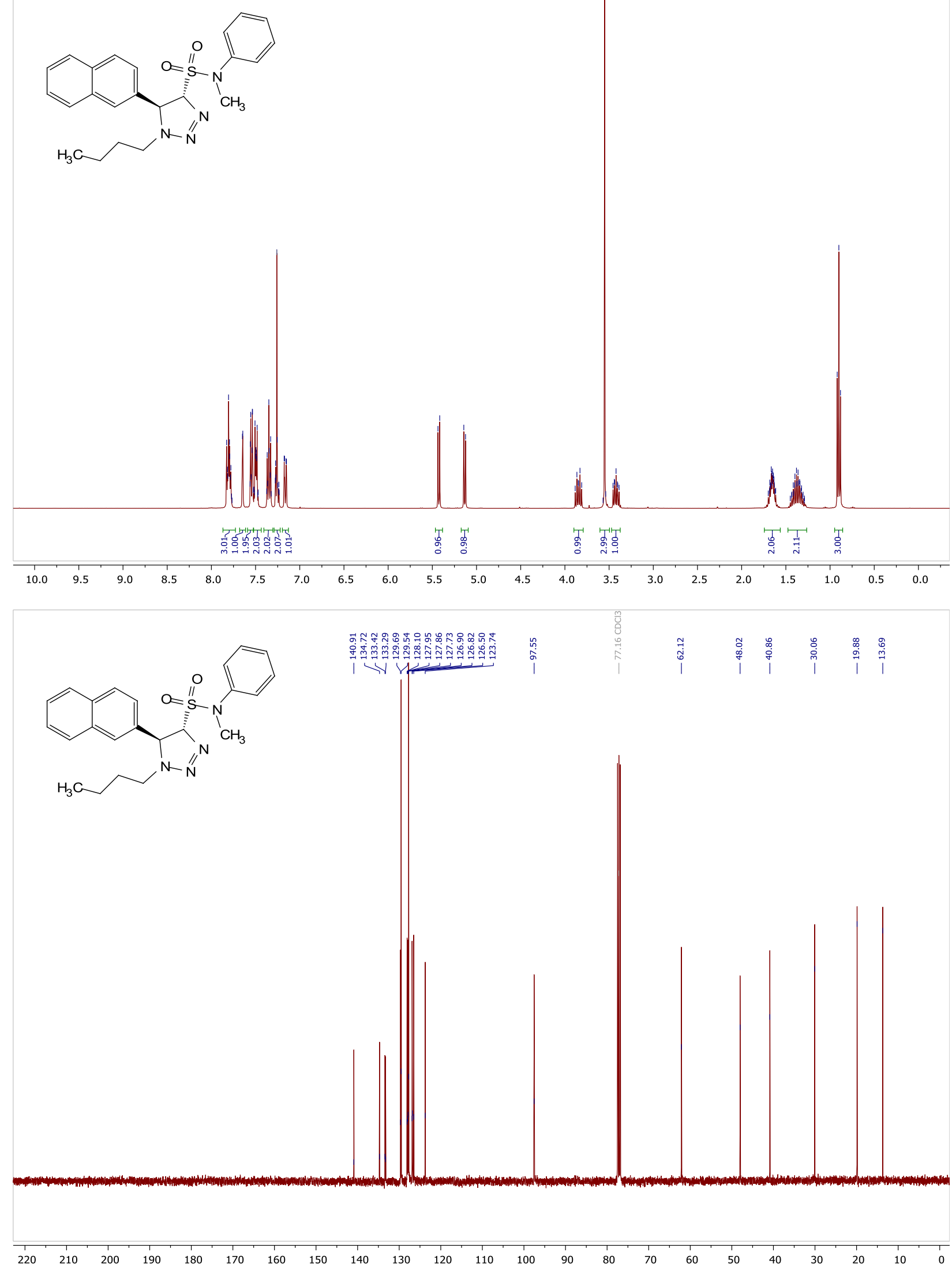
Copies of ${ }^{1} \mathbf{H},{ }^{13} \mathrm{C}\left\{{ }^{1} \mathrm{H}\right\}$ NMR and ${ }^{19} \mathbf{F}\left\{{ }^{1} \mathrm{H}\right\}$ spectra

Copies of ${ }^{1} \mathrm{H}\left(400.13 \mathrm{MHz}, \mathrm{CDCl}_{3}\right)$ and ${ }^{13} \mathrm{C}\left\{{ }^{1} \mathrm{H}\right\}\left(100.61 \mathrm{MHz}, \mathrm{CDCl}_{3}\right)$ spectra of aa

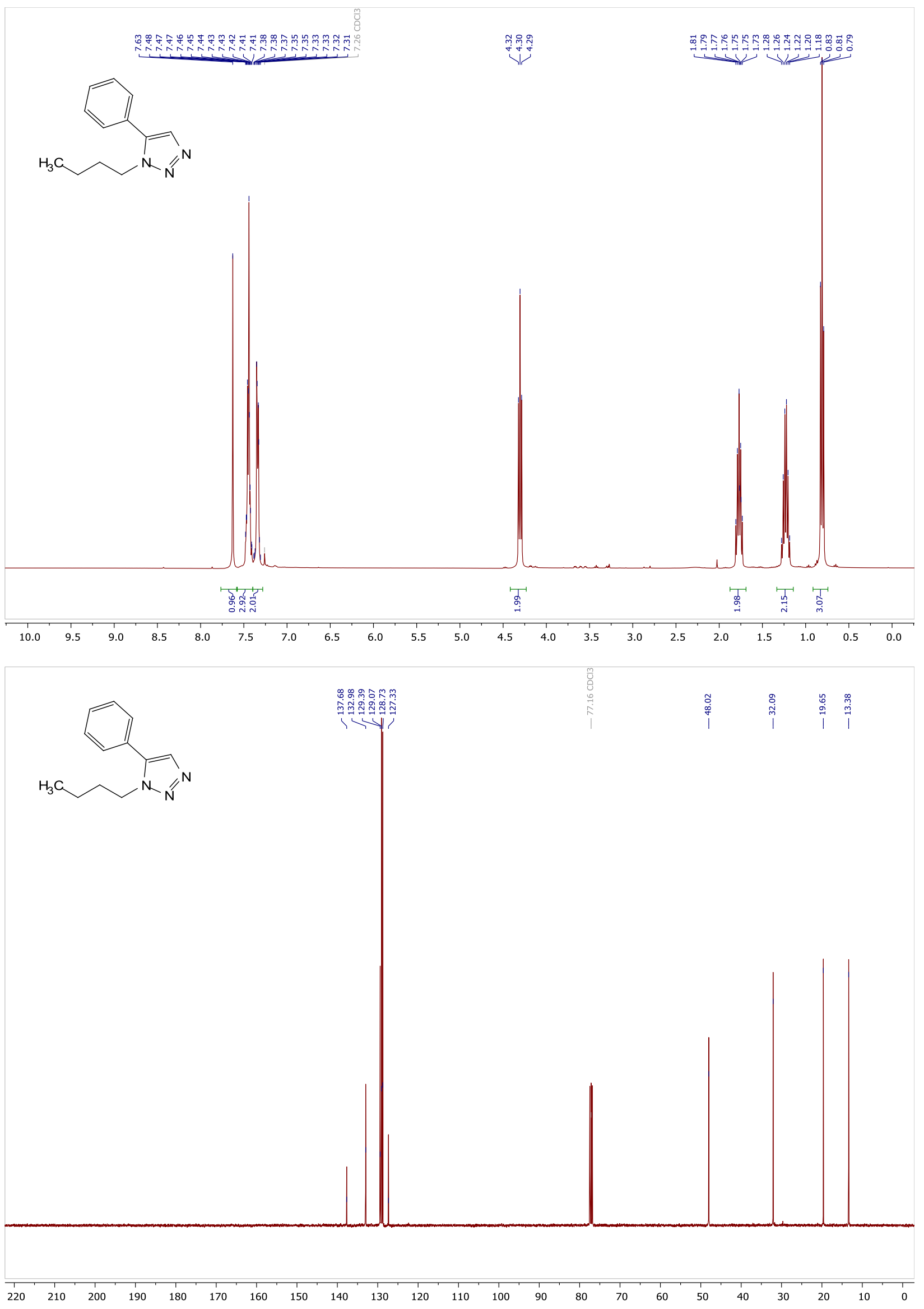

SF 
Copies of ${ }^{1} \mathrm{H}\left(400.13 \mathrm{MHz}, \mathrm{CDCl}_{3}\right)$ and ${ }^{13} \mathrm{C}\left\{{ }^{1} \mathrm{H}\right\}\left(100.61 \mathrm{MHz}, \mathrm{CDCl}_{3}\right)$ spectra of $\mathbf{5 b}$
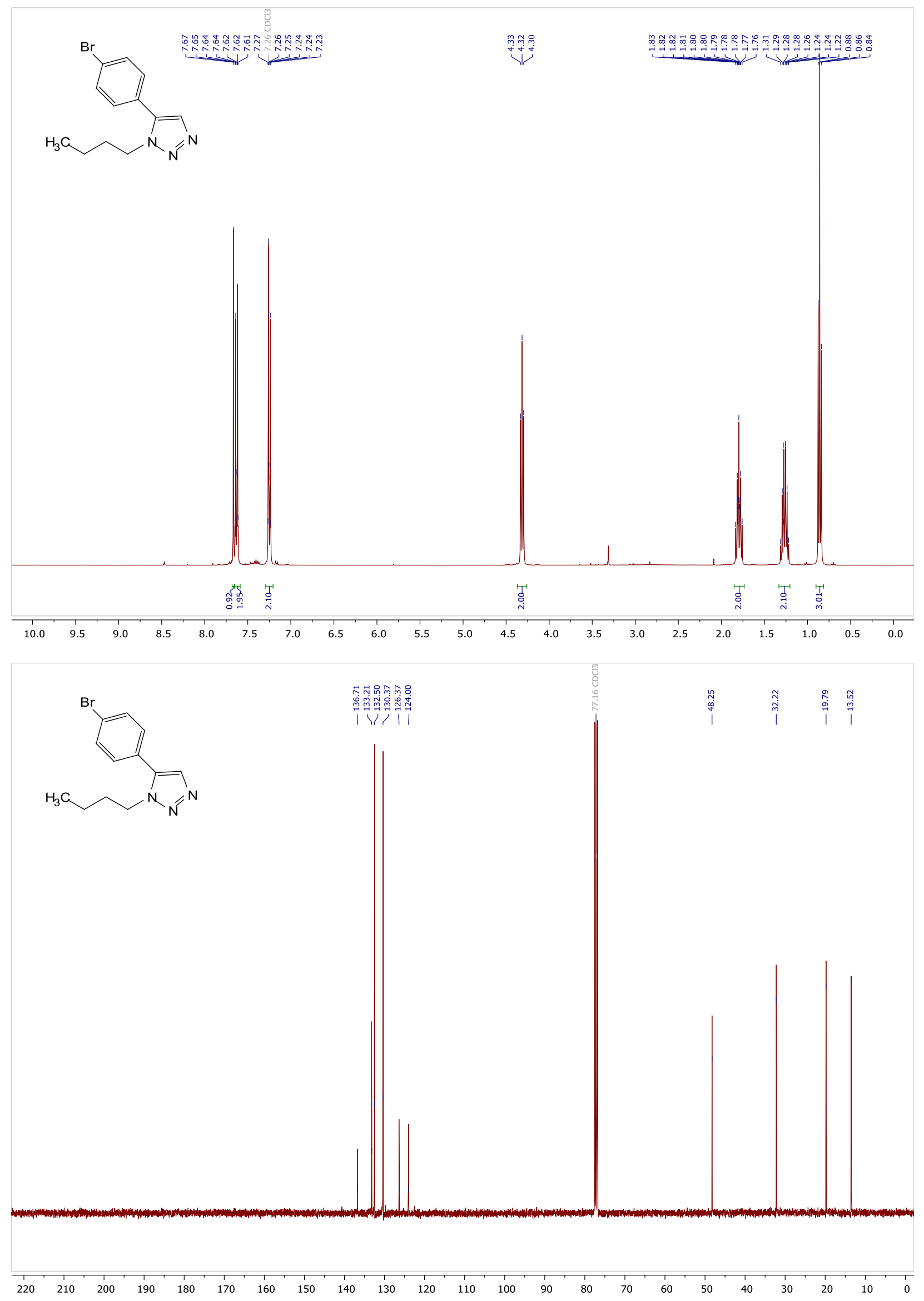

SG 
Copies of ${ }^{1} \mathrm{H}\left(400.13 \mathrm{MHz}, \mathrm{CDCl}_{3}\right),{ }^{13} \mathrm{C}\left\{{ }^{1} \mathrm{H}\right\}\left(100.61 \mathrm{MHz}, \mathrm{CDCl}_{3}\right)$ and ${ }^{19} \mathrm{~F}\left\{{ }^{1} \mathrm{H}\right\}\left(376.50 \mathrm{MHz}, \mathrm{CDCl}_{3}\right)$ spectra of 5c
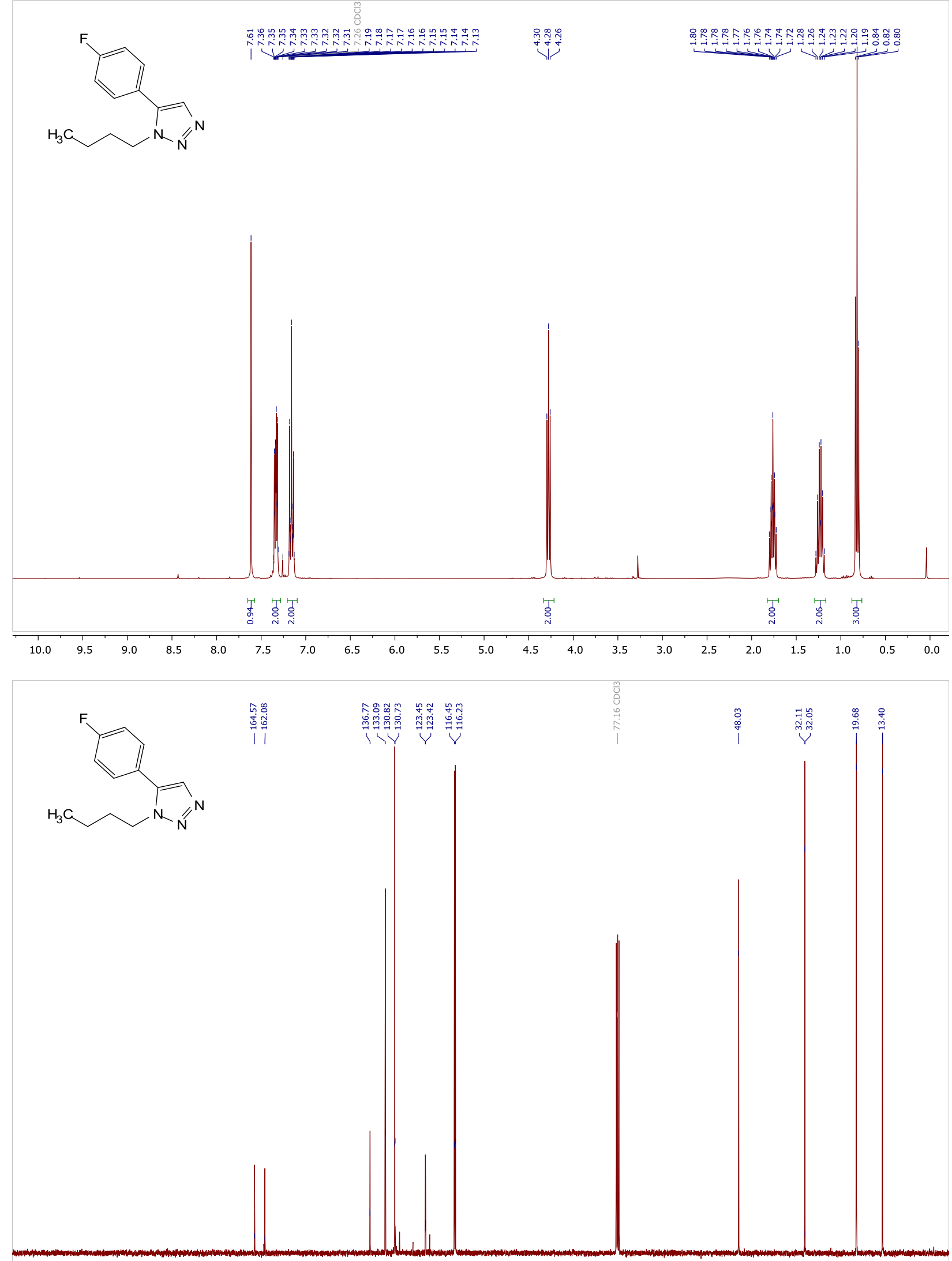

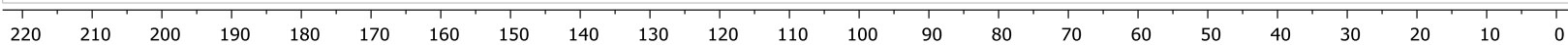




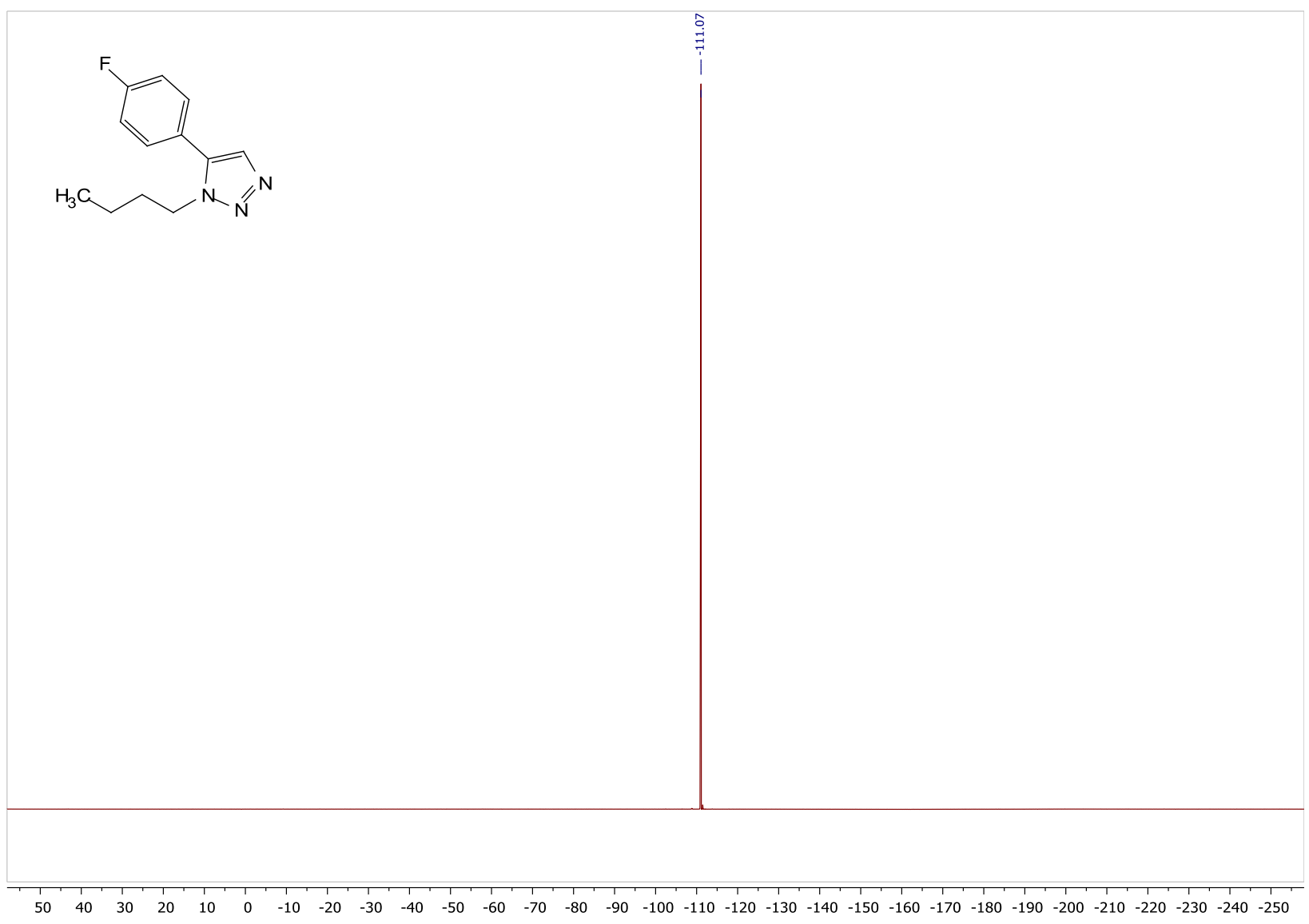

S8 
Copies of ${ }^{1} \mathrm{H}\left(400.13 \mathrm{MHz}, \mathrm{CDCl}_{3}\right)$ and ${ }^{13} \mathrm{C}\left\{{ }^{1} \mathrm{H}\right\}\left(100.61 \mathrm{MHz}, \mathrm{CDCl}_{3}\right)$ spectra of $\mathbf{5 d}$

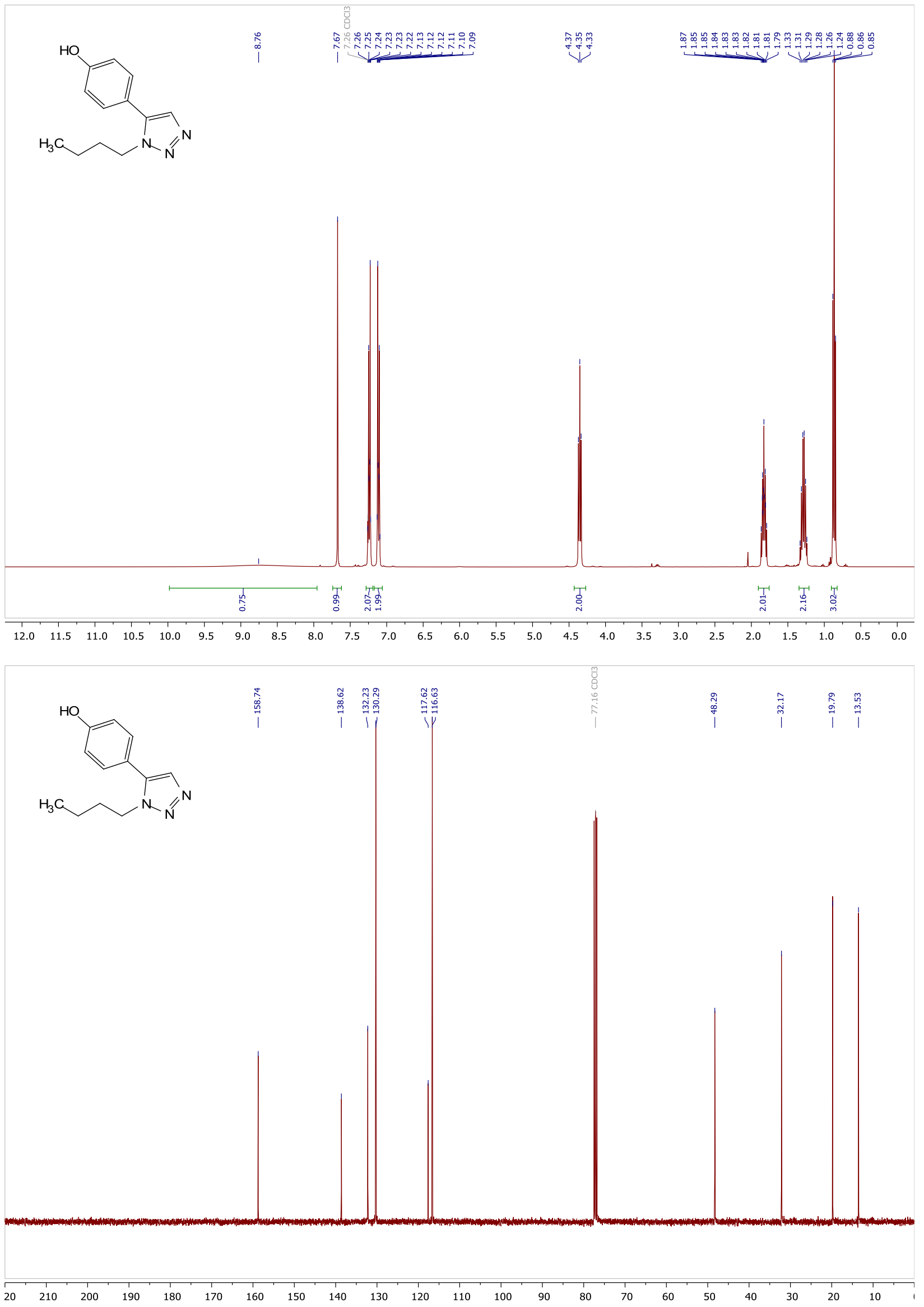

Sq 
Copies of ${ }^{1} \mathrm{H}\left(400.13 \mathrm{MHz}, \mathrm{CDCl}_{3}\right)$ and ${ }^{13} \mathrm{C}\left\{{ }^{1} \mathrm{H}\right\}\left(100.61 \mathrm{MHz}, \mathrm{CDCl}_{3}\right)$ spectra of $\mathbf{5 e}$

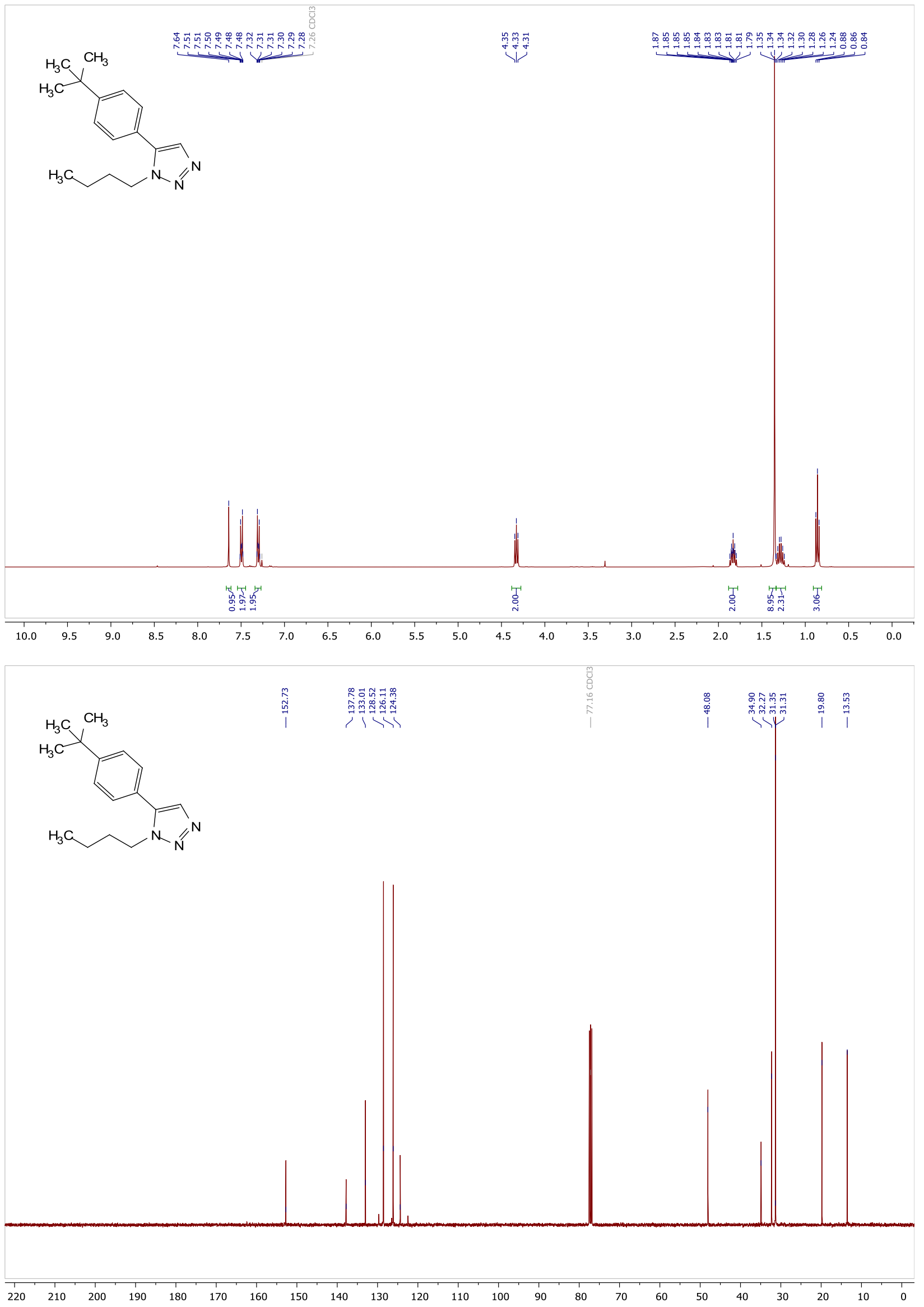

S10 
Copies of ${ }^{1} \mathrm{H}\left(400.13 \mathrm{MHz}, \mathrm{CDCl}_{3}\right)$ and ${ }^{13} \mathrm{C}\left\{{ }^{1} \mathrm{H}\right\}\left(100.61 \mathrm{MHz}, \mathrm{CDCl}_{3}\right)$ spectra of $\mathbf{5 f}$

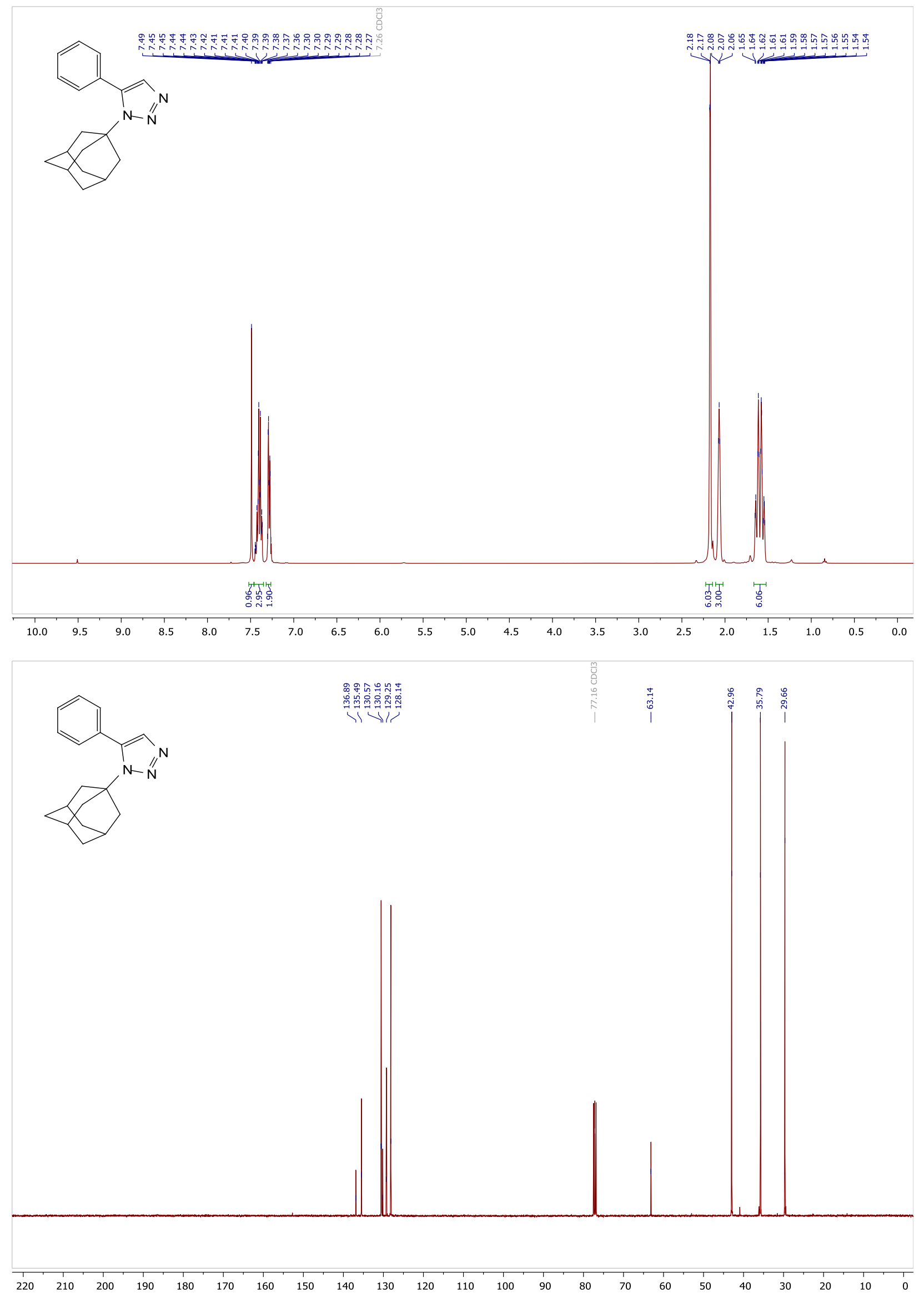


Copies of ${ }^{1} \mathrm{H}\left(400.13 \mathrm{MHz}, \mathrm{CDCl}_{3}\right)$ and ${ }^{13} \mathrm{C}\left\{{ }^{1} \mathrm{H}\right\}\left(100.61 \mathrm{MHz}, \mathrm{CDCl}_{3}\right)$ spectra of $\mathbf{5 g}$
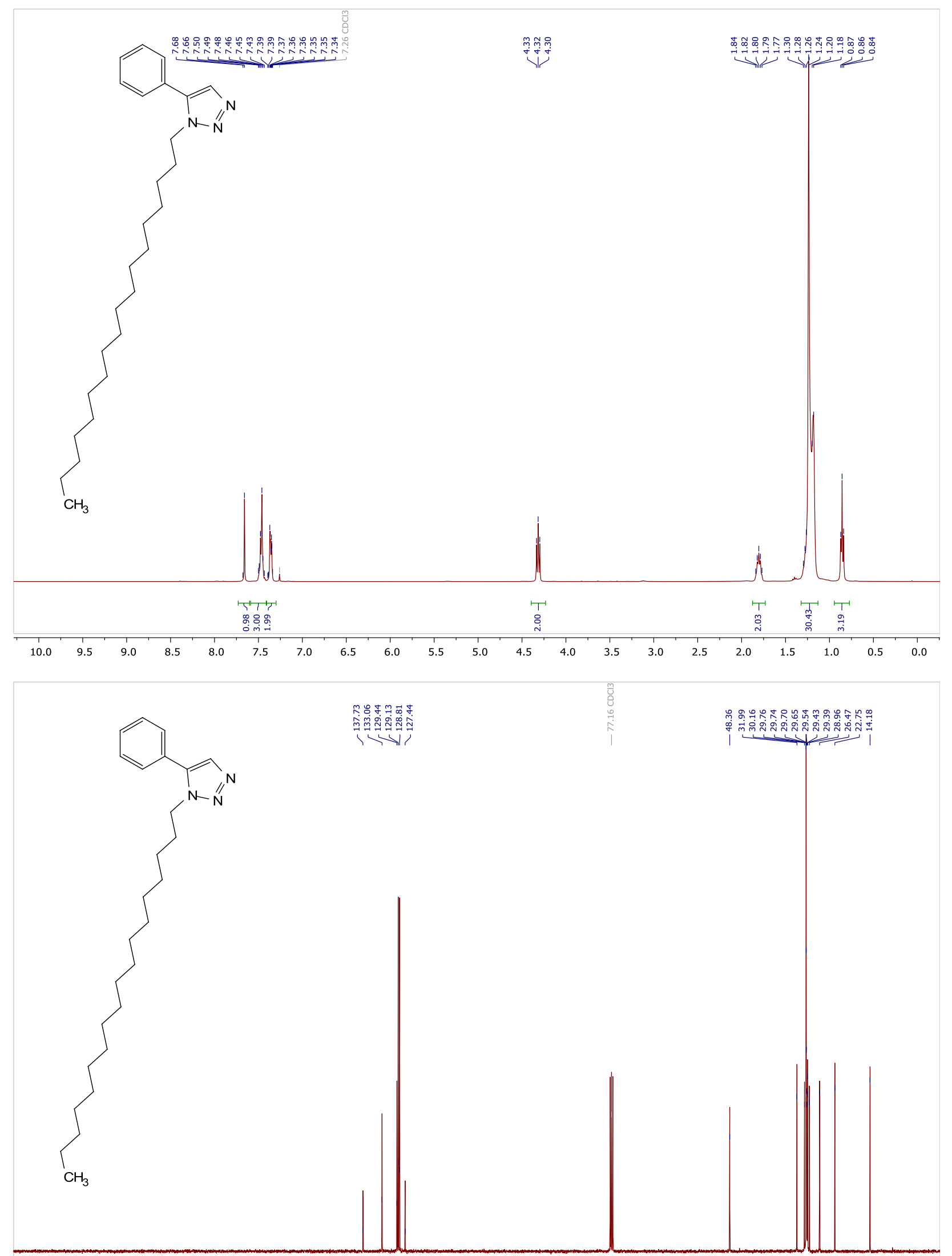

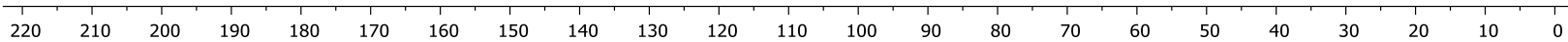


Copies of ${ }^{1} \mathrm{H}\left(400.13 \mathrm{MHz}, \mathrm{CDCl}_{3}\right)$ and ${ }^{13} \mathrm{C}\left\{{ }^{1} \mathrm{H}\right\}\left(100.61 \mathrm{MHz}, \mathrm{CDCl}_{3}\right)$ spectra of $\mathbf{5 h}$
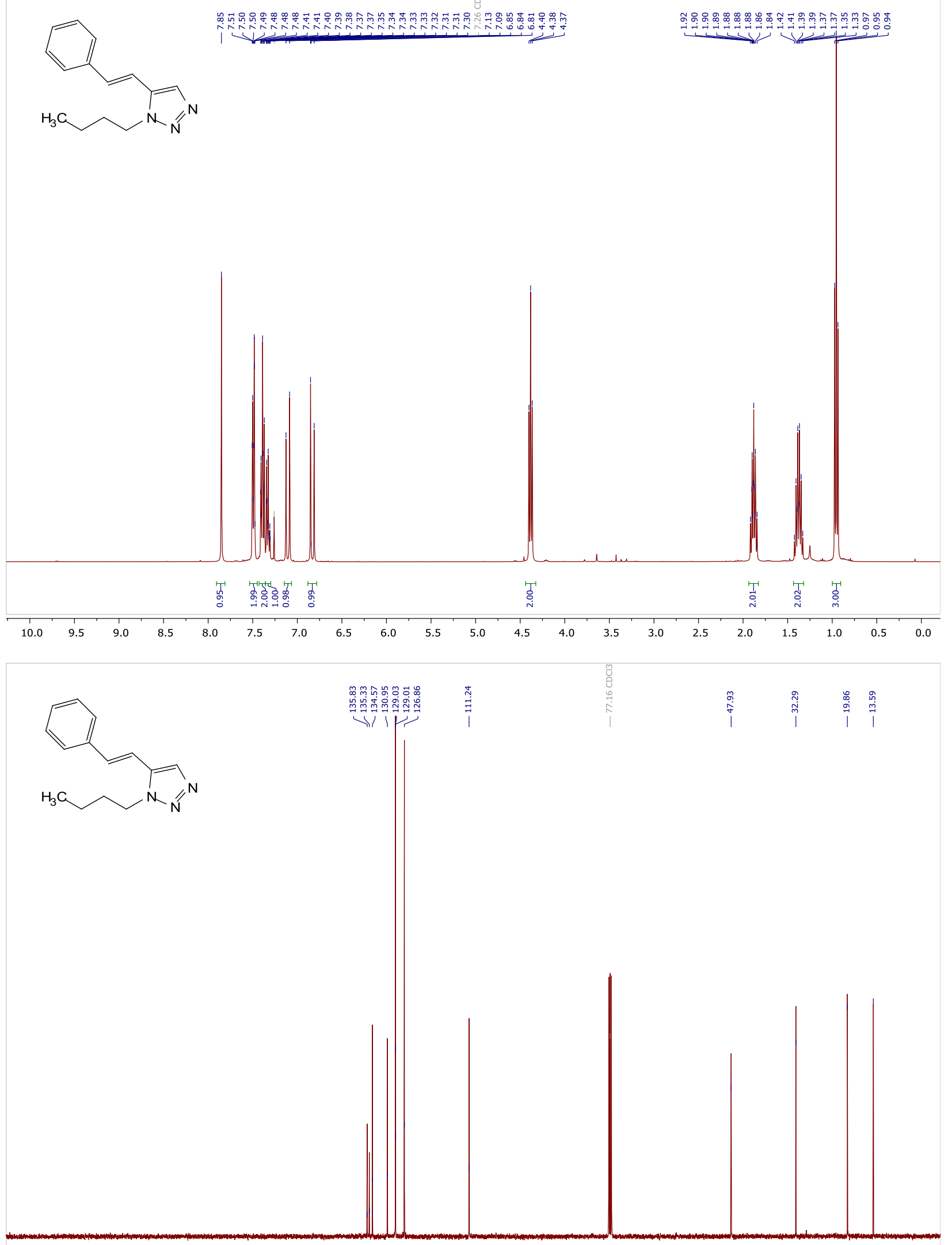

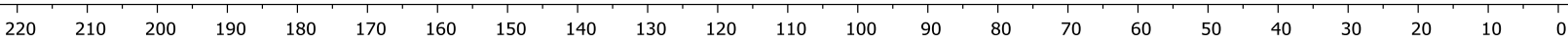


Copies of ${ }^{1} \mathrm{H}\left(400.13 \mathrm{MHz}, \mathrm{CDCl}_{3}\right)$ and ${ }^{13} \mathrm{C}\left\{{ }^{1} \mathrm{H}\right\}\left(100.61 \mathrm{MHz}, \mathrm{CDCl}_{3}\right)$ spectra of $\mathbf{5 i}$
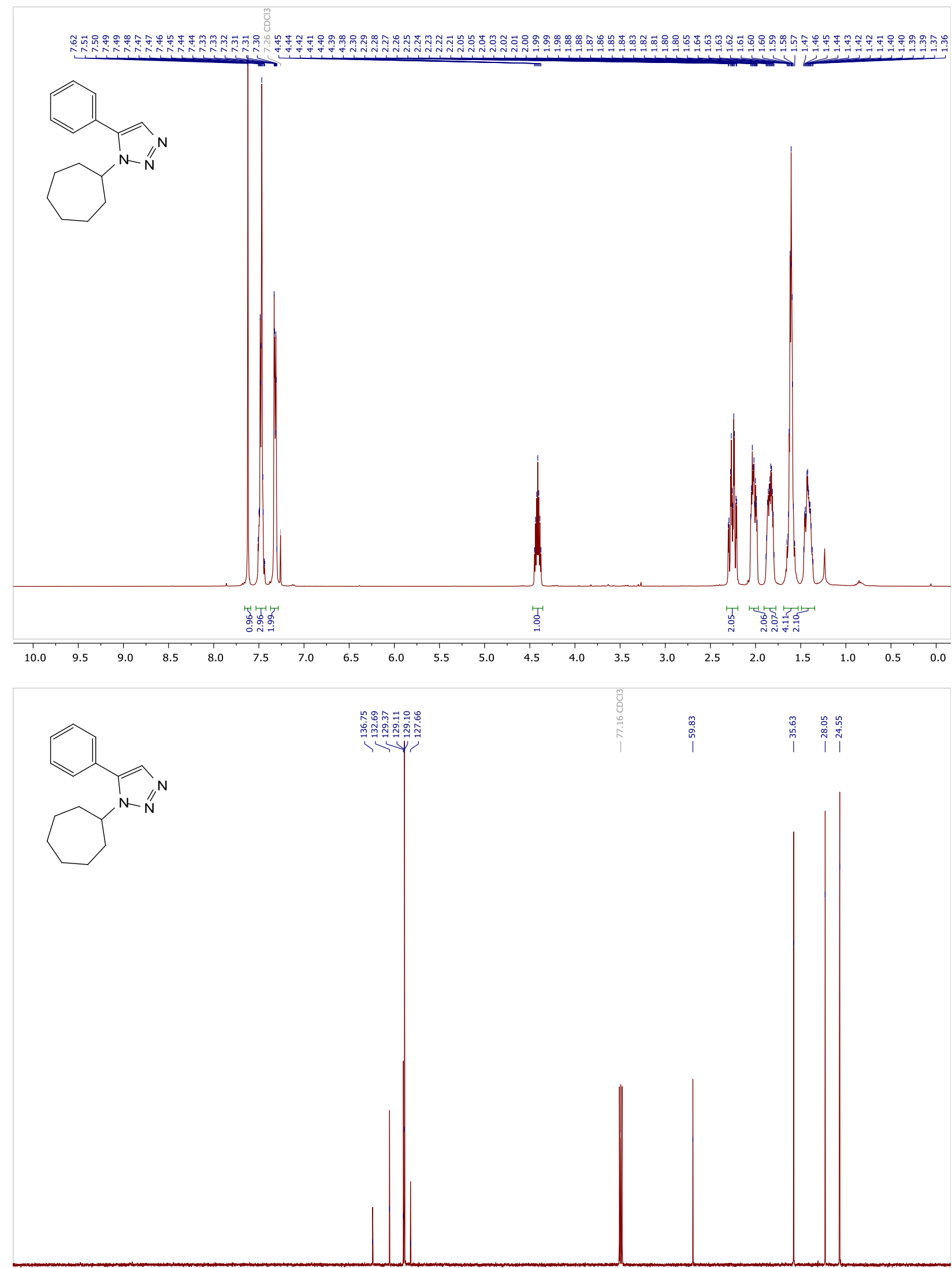

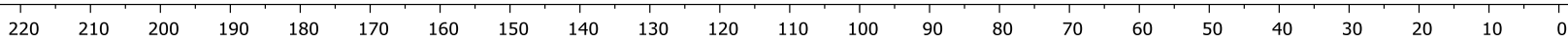


Copies of ${ }^{1} \mathrm{H}\left(400.13 \mathrm{MHz}, \mathrm{CDCl}_{3}\right)$ and ${ }^{13} \mathrm{C}\left\{{ }^{1} \mathrm{H}\right\}\left(100.61 \mathrm{MHz}, \mathrm{CDCl}_{3}\right)$ spectra of $\mathbf{5} \mathbf{j}$

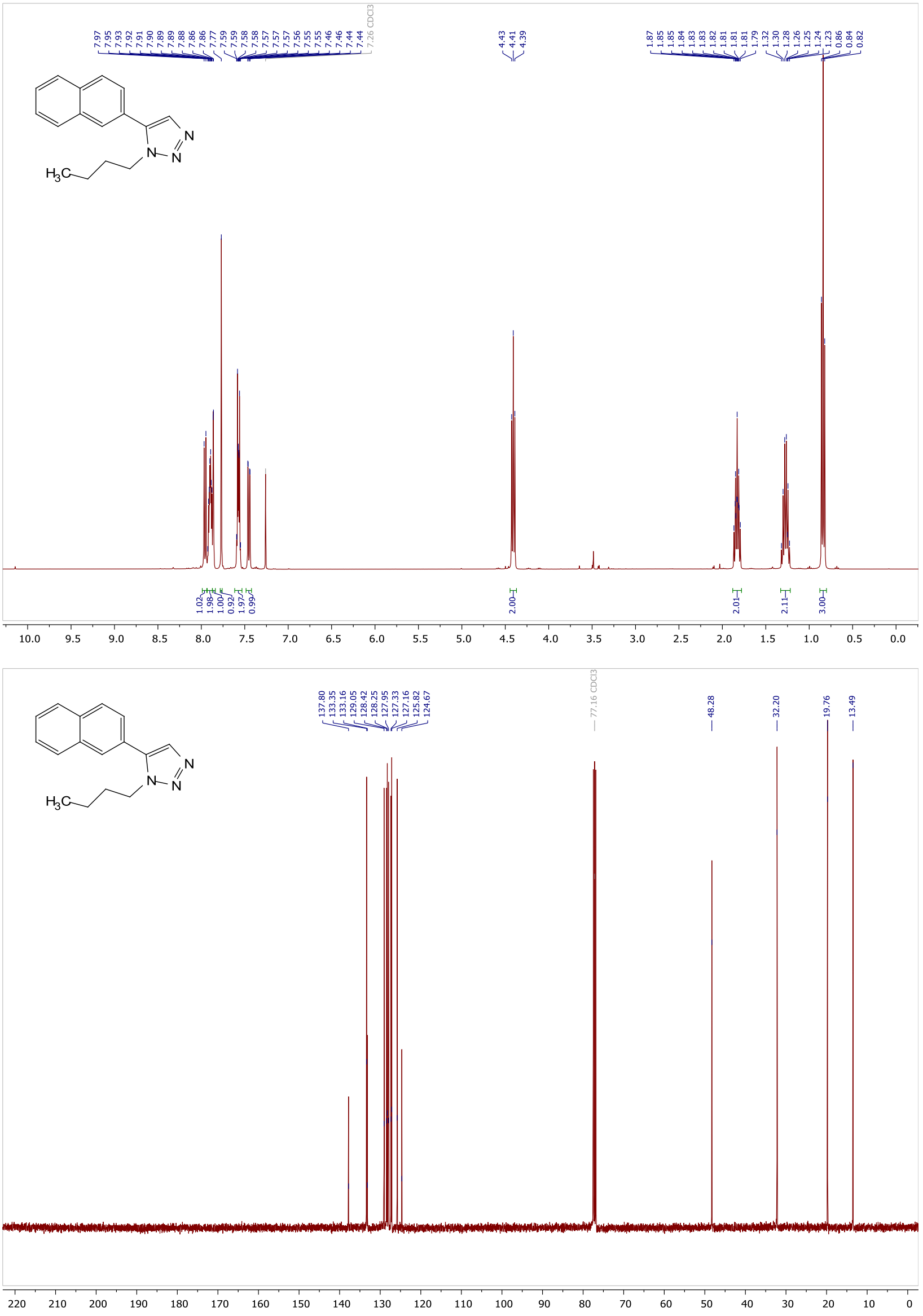


Copies of ${ }^{1} \mathrm{H}\left(400.13 \mathrm{MHz}, \mathrm{CDCl}_{3}\right)$ and ${ }^{13} \mathrm{C}\left\{{ }^{1} \mathrm{H}\right\}\left(100.61 \mathrm{MHz}, \mathrm{CDCl}_{3}\right)$ spectra of $\mathbf{5 k}$
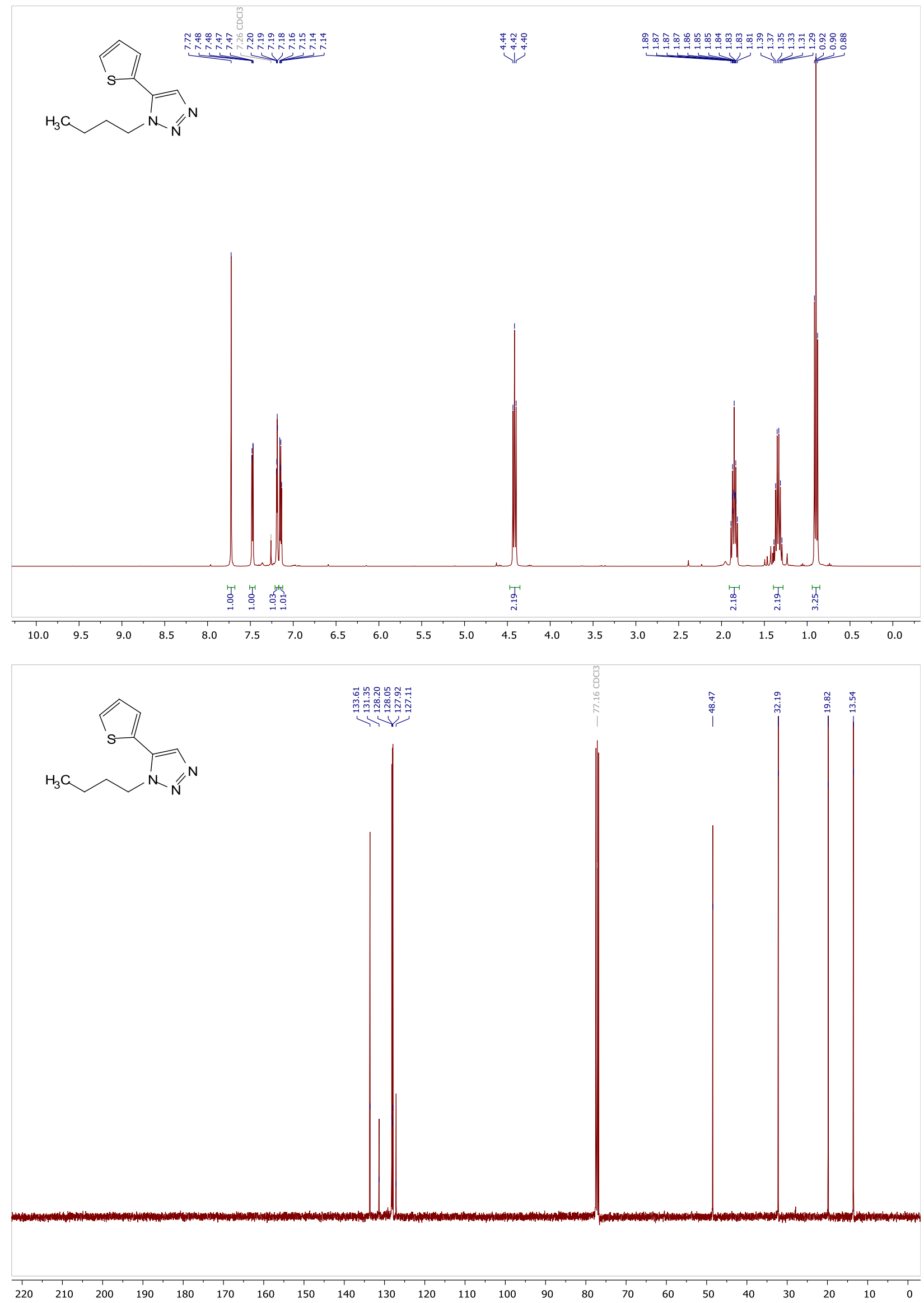
Copies of ${ }^{1} \mathrm{H}\left(400.13 \mathrm{MHz}, \mathrm{CDCl}_{3}\right)$ and ${ }^{13} \mathrm{C}\left\{{ }^{1} \mathrm{H}\right\}\left(100.61 \mathrm{MHz}, \mathrm{CDCl}_{3}\right)$ spectra of $\mathbf{5 l}$
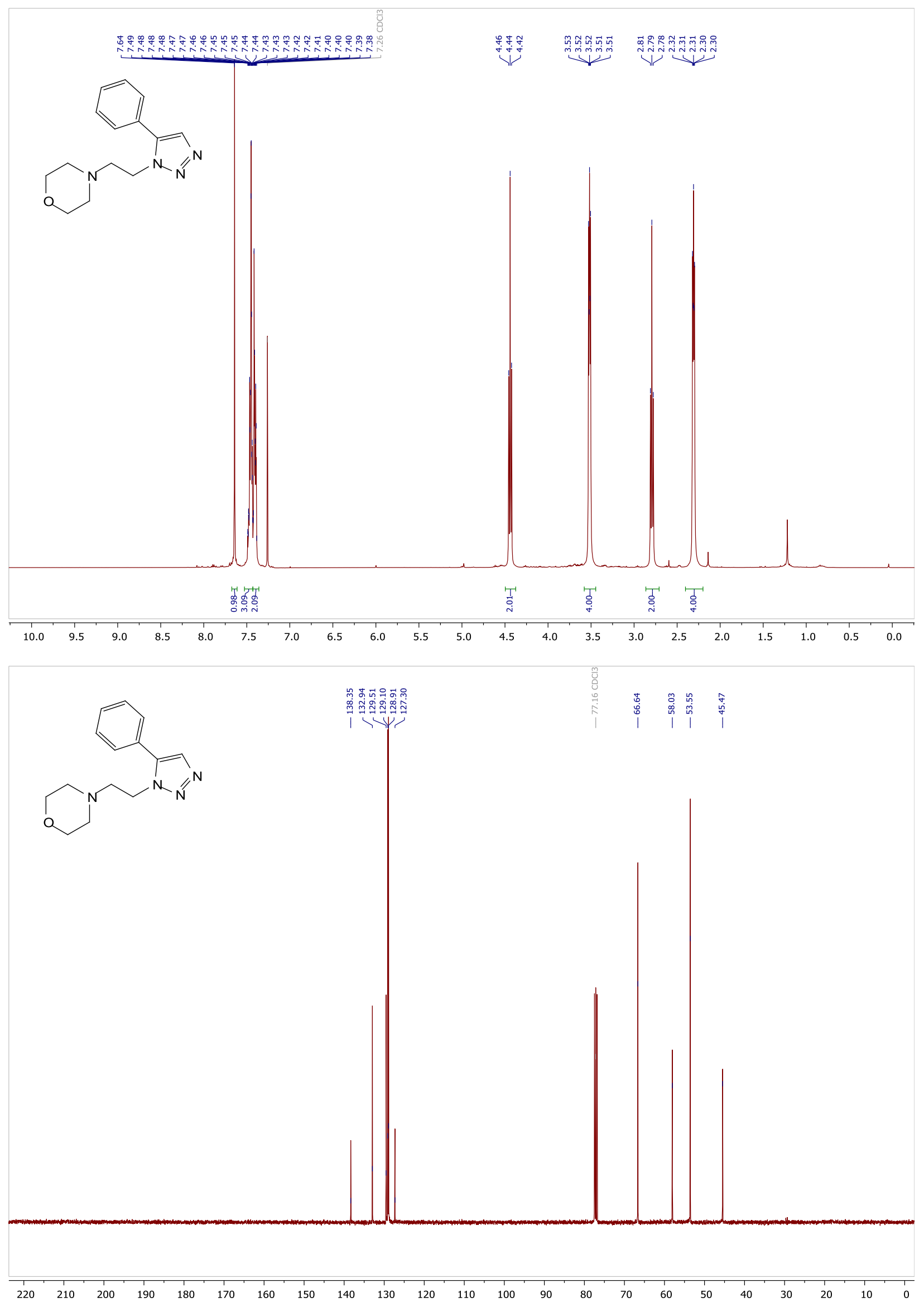

S17 
Copies of ${ }^{1} \mathrm{H}\left(400.13 \mathrm{MHz}, \mathrm{CDCl}_{3}\right)$ and ${ }^{13} \mathrm{C}\left\{{ }^{1} \mathrm{H}\right\}\left(100.61 \mathrm{MHz}, \mathrm{CDCl}_{3}\right)$ spectra of $\mathbf{5 m}$
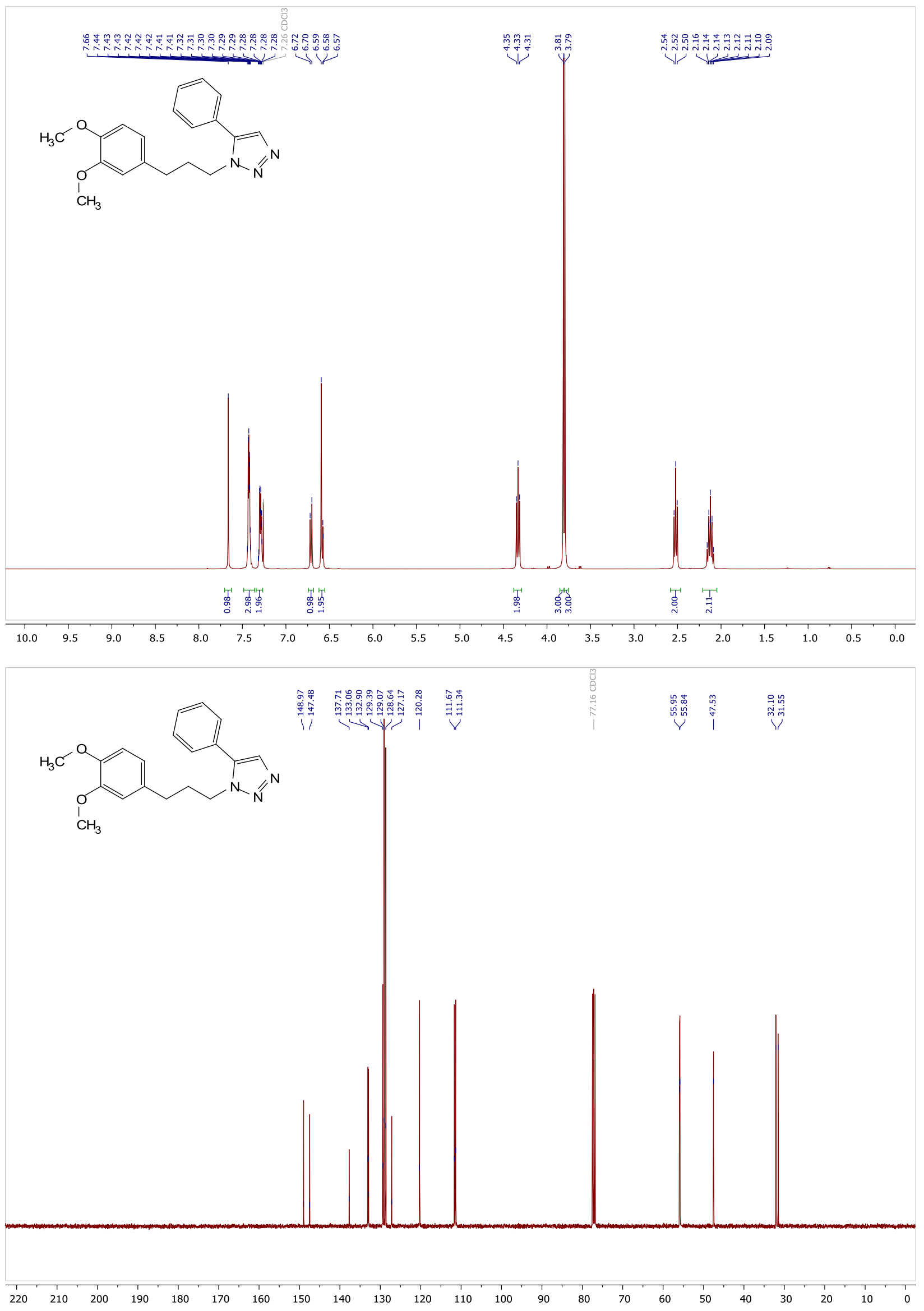

S18 
Copies of ${ }^{1} \mathrm{H}\left(400.13 \mathrm{MHz}, \mathrm{CDCl}_{3}\right)$ and ${ }^{13} \mathrm{C}\left\{{ }^{1} \mathrm{H}\right\}\left(100.61 \mathrm{MHz}, \mathrm{CDCl}_{3}\right)$ spectra of $\mathbf{5 n}$
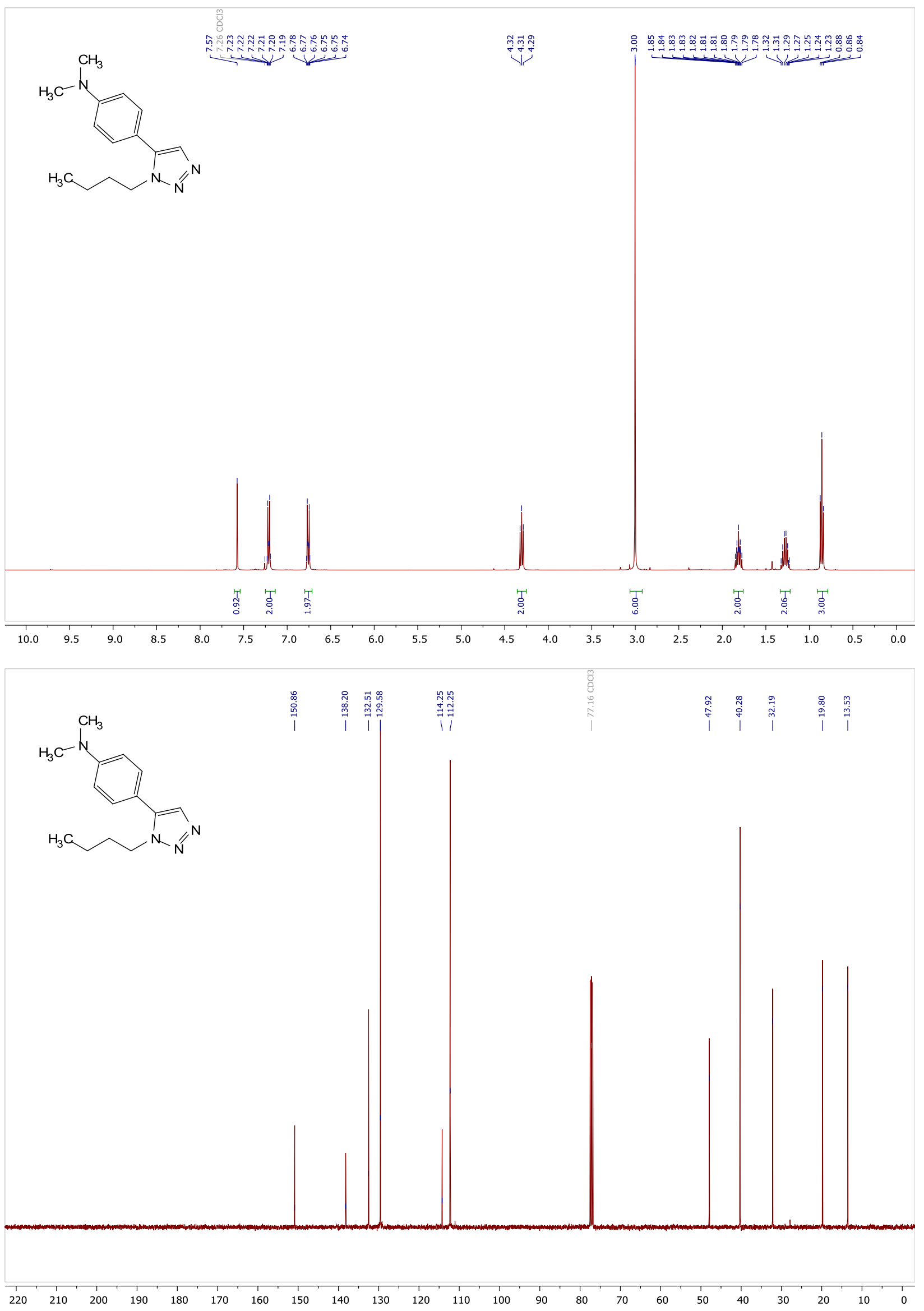

S19 
Copies of ${ }^{1} \mathrm{H}\left(400.13 \mathrm{MHz}, \mathrm{CDCl}_{3}\right)$ and ${ }^{13} \mathrm{C}\left\{{ }^{1} \mathrm{H}\right\}\left(100.61 \mathrm{MHz}, \mathrm{CDCl}_{3}\right)$ spectra of $\mathbf{5 o}$
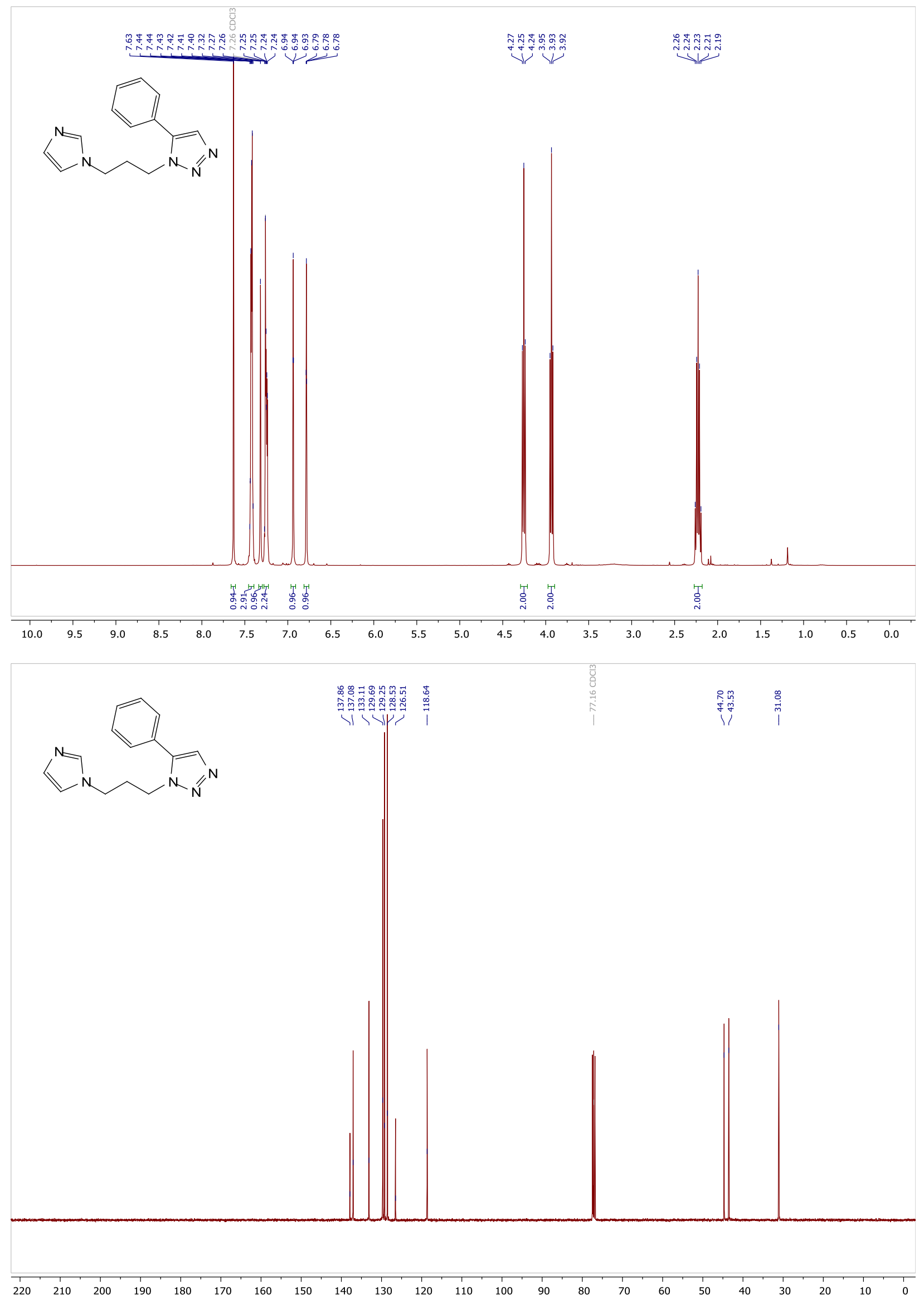

S20 
Copies of ${ }^{1} \mathrm{H}\left(400.13 \mathrm{MHz}, \mathrm{CDCl}_{3}\right)$ and ${ }^{13} \mathrm{C}\left\{{ }^{1} \mathrm{H}\right\}\left(100.61 \mathrm{MHz}, \mathrm{CDCl}_{3}\right)$ spectra of $\mathbf{5 p}$
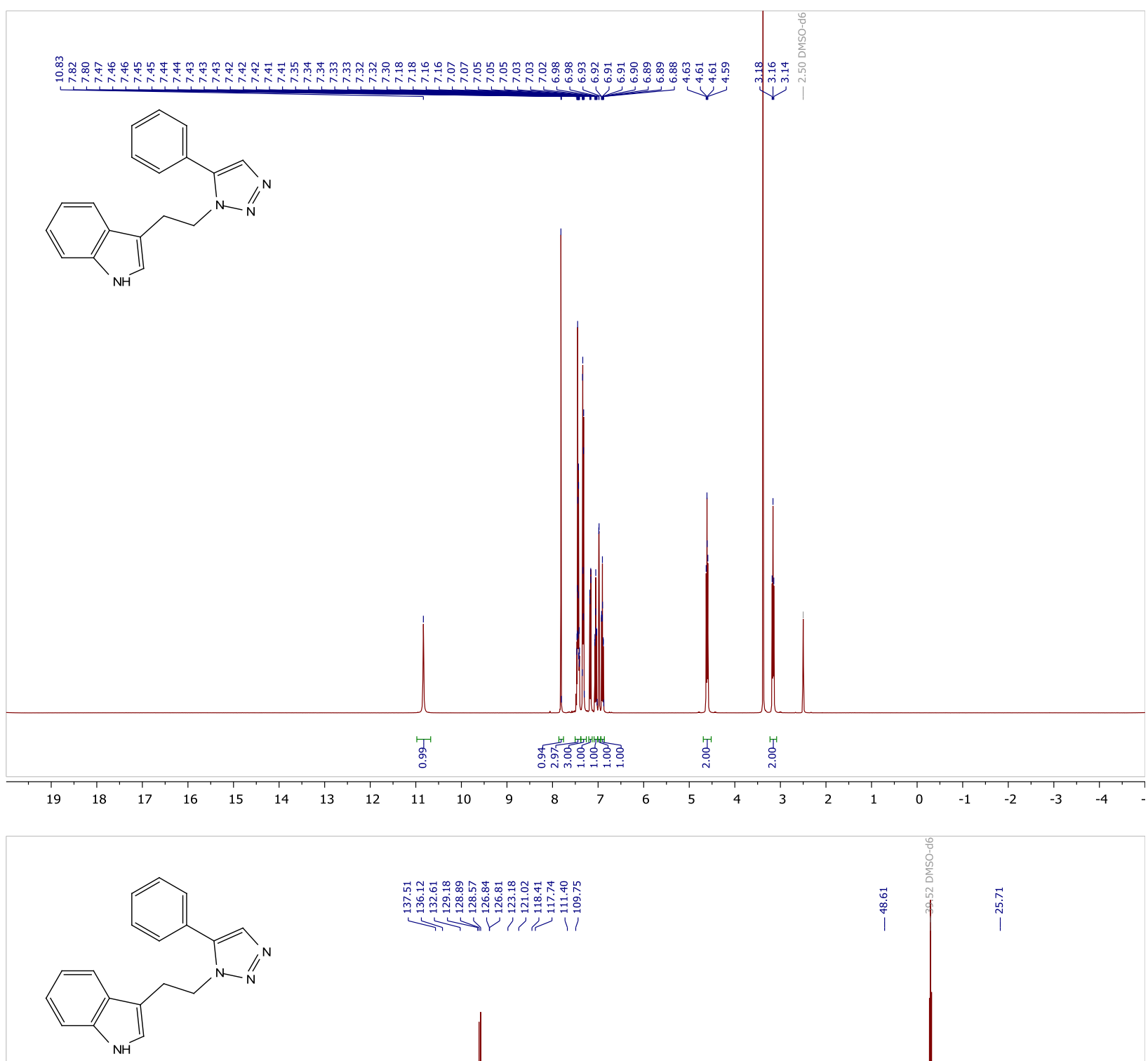

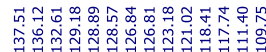

年

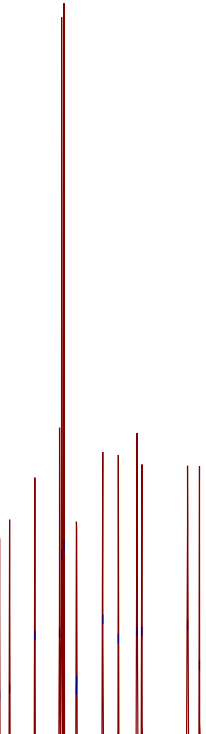


Copies of ${ }^{1} \mathrm{H}\left(400.13 \mathrm{MHz}, \mathrm{CDCl}_{3}\right)$ and ${ }^{13} \mathrm{C}\left\{{ }^{1} \mathrm{H}\right\}\left(100.61 \mathrm{MHz}, \mathrm{CDCl}_{3}\right)$ spectra of $\mathbf{5 q}$<smiles>CCCCn1nncc1-c1cccc(OC)c1OC</smiles>

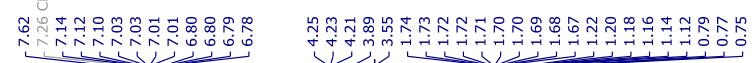

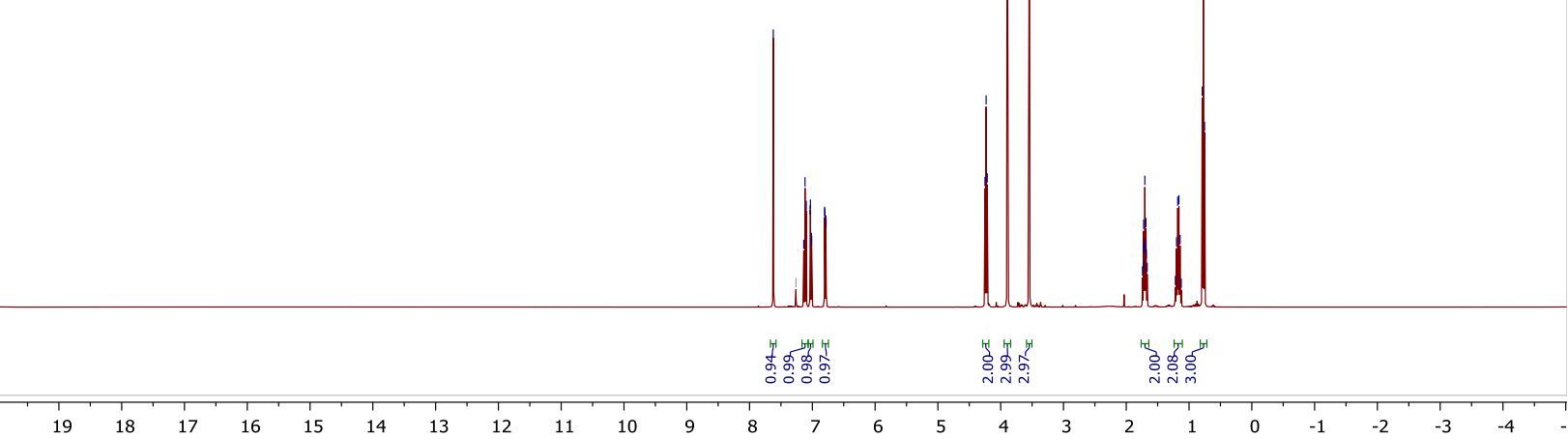<smiles>CCCCn1nncc1-c1cccc(OC)c1OC</smiles>

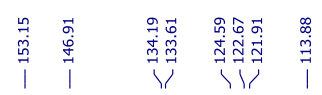

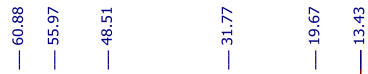

$\sim \mathrm{N}^{\prime}$

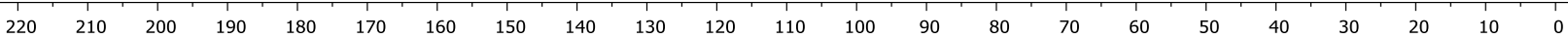


Copies of ${ }^{1} \mathrm{H}\left(400.13 \mathrm{MHz}, \mathrm{CDCl}_{3}\right)$ and ${ }^{13} \mathrm{C}\left\{{ }^{1} \mathrm{H}\right\}\left(100.61 \mathrm{MHz}, \mathrm{CDCl}_{3}\right)$ spectra of $\mathbf{5 r}$
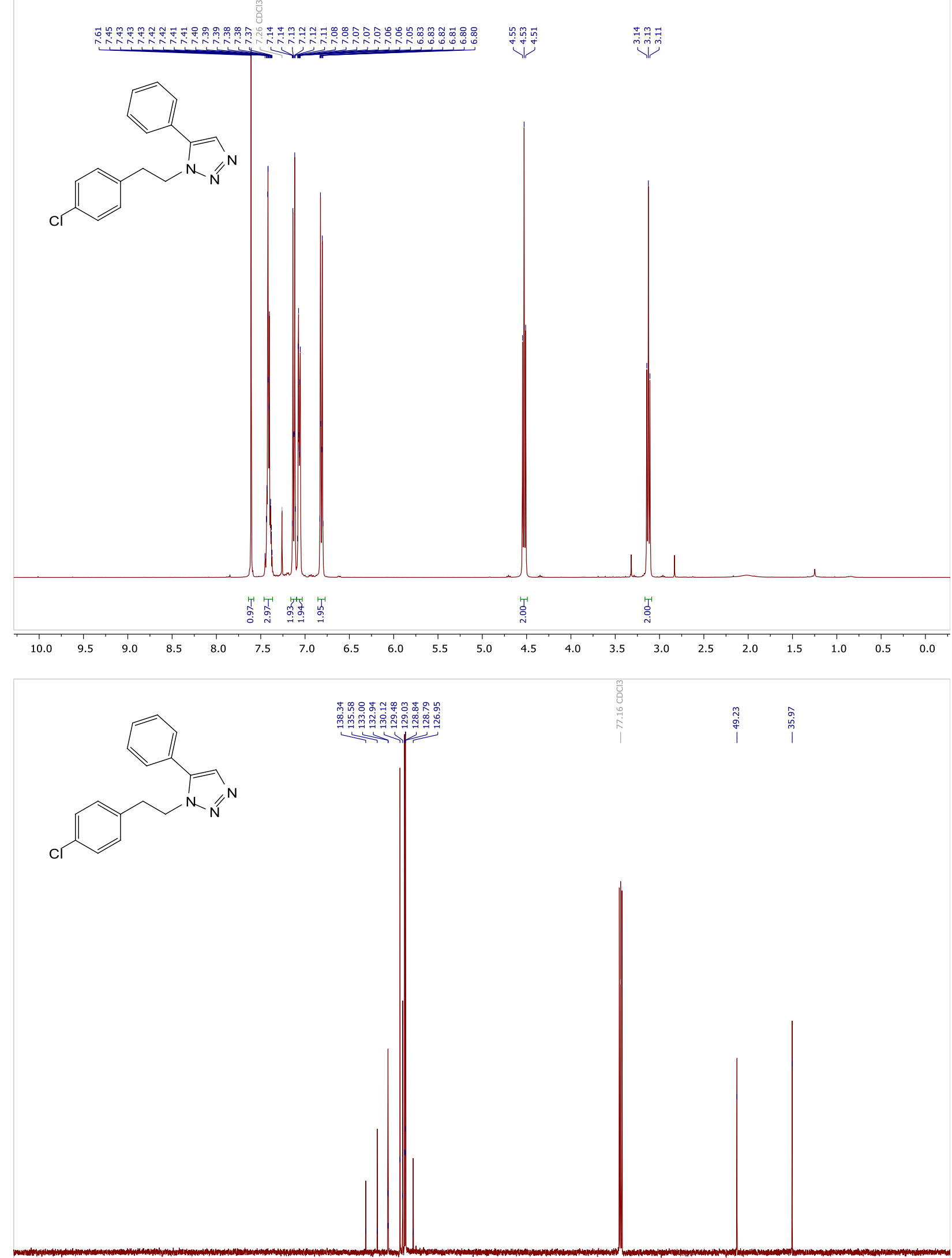

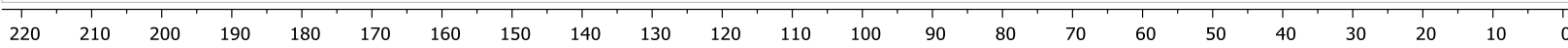

